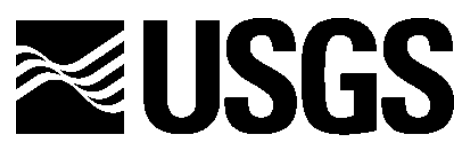

science for a changing world

A Preliminary Report to the U.S. Coast Guard, Part 2

\title{
A Survey of Microbial Community Diversity in Marine Sediments Impacted by Petroleum Hydrocarbons from the Gulf of Mexico and Atlantic Shorelines, Texas to Florida
}

By John T. Lisle and Sarah H. Stellick

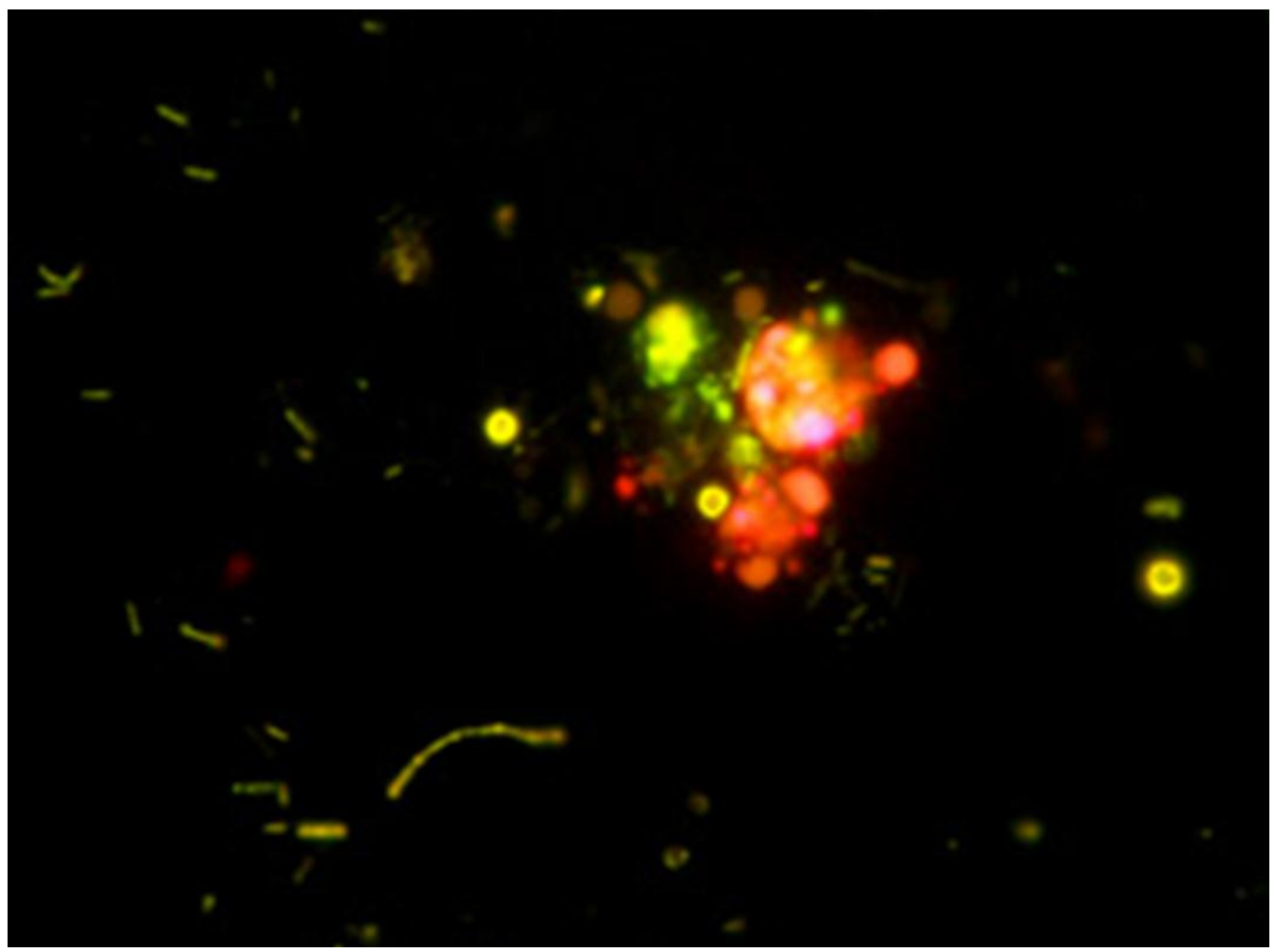

Open-File Report 2011-1151

U.S. Department of the Interior

U.S. Geological Survey 


\section{U.S. Department of the Interior \\ KEN SALAZAR, Secretary}

\section{U.S. Geological Survey \\ Marcia K. McNutt, Director}

U.S. Geological Survey, Reston, Virginia 2011

For product and ordering information:

World Wide Web: http://www.usgs.gov/pubprod

Telephone: 1-888-ASK-USGS

For more information on the USGS - the Federal source for science about the Earth, its natural and living resources, natural hazards, and the environment:

World Wide Web: http://www.usgs.gov

Telephone: 1-888-ASK-USGS

Suggested citation:

Lisle, J.T., and Stellick, S.H., 2011, A survey of microbial community diversity in marine sediments impacted by petroleum hydrocarbons from the Gulf of Mexico and Atlantic shorelines, Texas to Florida: U.S. Geological Survey Open File-Report 2011-1151, 20p.

Front cover image:

Naturally occurring microbial community stained SYBR Gold® using epi-fluorescent microscopy at $1250 \times$ magnification.

Any use of trade, product, or firm names is for descriptive purposes only and does not imply endorsement by the U.S. Government.

Although this report is in the public domain, permission must be secured from the individual copyright owners to reproduce any copyrighted material contained within this report. 


\section{Contents}

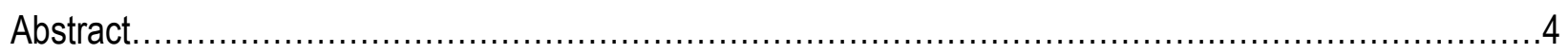

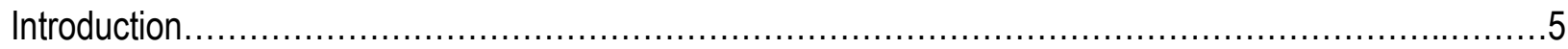

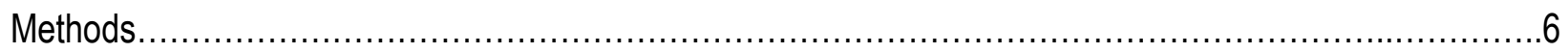

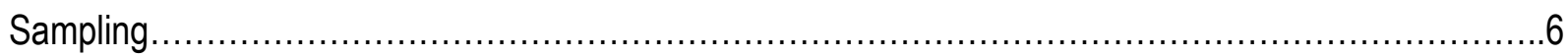

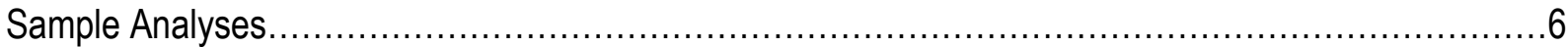

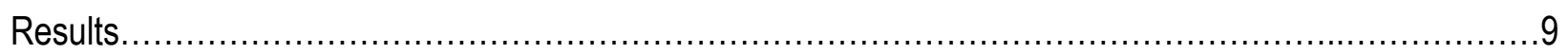

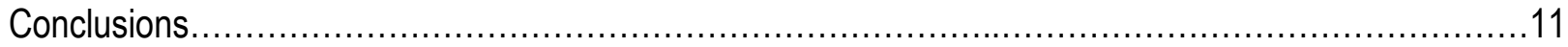

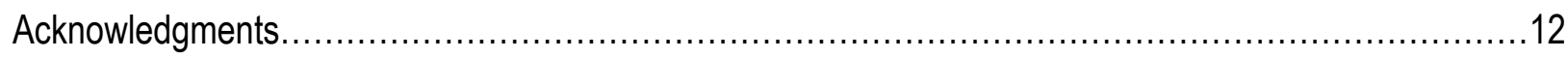

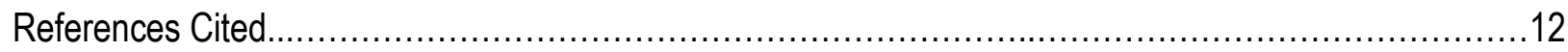

Figure 1. Sediment sample sites, Gulf of Mexico and Atlantic shorelines. A, Texas to Louisiana; B, Louisiana to Alabama; C, Florida ................................................................... 14-17

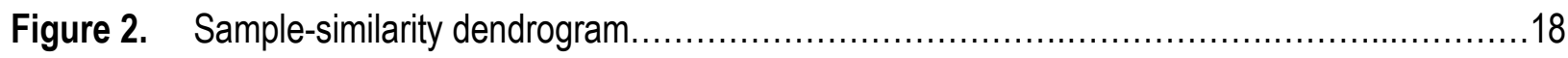

\section{Tables}

Table 1. Sediment sample site descriptions and locations. 


\section{A Survey of Microbial Community Diversity in Marine}

\section{Sediments Impacted by Petroleum Hydrocarbons from}

\section{the Gulf of Mexico and Atlantic Shorelines, Texas to}

\section{Florida}

By John T. Lisle and Sarah H. Stellick

\section{Abstract}

Microbial community genomic DNA was extracted from sediment samples collected along the Gulf of Mexico and Atlantic coasts from Texas to Florida. Sample sites were identified as being ecologically sensitive and (or) as having high potential of being impacted by Macondo-1 (M-1) well oil from the Deepwater Horizon blowout. The diversity within the microbial communities associated with the collected sediments provides a baseline dataset to which microbial community-diversity data from impacted sites could be compared. To determine the microbial community diversity in the samples, genetic fingerprints were generated and compared. Specific sequences within the community genomic DNA were first amplified using the polymerase chain reaction (PCR) with a primer set that provides possible resolution to the species level. A second nested PCR was performed on the primary PCR products using a primer set on which a GC-clamp was attached to one of the primers. The nested PCR products were separated using denaturing-gradient gel electrophoresis (DGGE) that resolves the nested PCR 
products based on sequence dissimilarities (or similarities), forming a genomic fingerprint of the microbial diversity within the respective samples. Samples with similar fingerprints were grouped and compared to oil-fingerprint data from the same sites (Rosenbauer and others, 2011). The microbial community fingerprints were generally grouped into sites that had been shown to contain background concentrations of non-Deepwater Horizon oil. However, these groupings also included sites where no oil signature was detected. This report represents some of the first information on naturally occurring microbial communities in sediment from shorelines along the Gulf of Mexico and Atlantic coasts from Texas to Florida.

\section{Introduction}

From April 20 to July 15, 2010, approximately 4.4 million barrels of crude oil from the Deepwater Horizon oil rig discharged into the Gulf of Mexico (Crone and Tolstoy, 2010). The oil, classified as Macondo-1, was estimated to cover 68,000 square miles as a surface-water layer (Amos, 2010). In response to this spill and before oil associated with this spill made landfall, the U.S. Geological Survey (USGS) collected near-surface beach and coastal sediments at 63 sites along the coasts of Texas, Louisiana, Mississippi, Alabama, and Florida for microbiological analyses. Sites were selected to include various shoreline types-for example, sandy beaches, wetlands, marshes, and barrier islands. The purpose of this project was to establish the background, or pre-spill, diversity of microbial communities within the sediments. 


\section{Methods}

\section{Sampling}

Shoreline sediments were collected from 63 sites (table 1 and fig. 1) that had been identified as locations with a high potential of being impacted by oil released from the Deepwater Horizon spill in the Gulf of Mexico. These sites had not been contaminated with oil from the Deepwater Horizon spill at the time of their sampling. Samples were collected from May 7 to June 16, 2010, along the Gulf of Mexico and Atlantic shorelines in Texas, Louisiana, Mississippi, and Alabama and along the Gulf of Mexico and Alantic shorelines of Florida. Replicate samples were collected from the following sites: TX-51 (3 replicates), LA-23 (2 replicates), LA-31 (3 replicates), MS-38 (2 replicates), MS-45 (4 replicates), FL-6 (3 replicates), FL-7 (2 replicates), FL-11 (3 replicates), FL-16 (2 replicates), and FL-18 (2 replicates). All samples were collected, processed, and shipped as described in the USGS National Field Manual for the Collection of Water-Quality Data (NFM) (http://pubs.water.usgs.gov/twri9A/) (U.S. Geological Survey, variously dated), and Sampling Protocol for Post-Landfall Deepwater Horizon Oil Release, Gulf of Mexico, 2010 (http://pubs.usgs.gov/of/2010/1191/) (Wilde and others, 2010). This set of manuals includes all of the protocols and methods that ensured sample integrity, consistency, and data reliability for the entire project.

\section{Sample Analyses}

All samples were processed and analyzed at the USGS Coastal and Marine Science Center in St. Petersburg, Fla. Samples were kept frozen at $-80^{\circ} \mathrm{C}$ until processing. Processing included the aseptic subsampling of each sample into sterile dishes with lids. Each subsample was allowed to thaw at room temperature. Once thawed, each subsample was gently and 
aseptically mixed and an aliquot (approximately 25 grams, g) transferred to a sterile 50-milliliter $(\mathrm{mL})$ tube. The original sample and subsamples were stored at $-80^{\circ} \mathrm{C}$ until needed for the next step of processing.

The sediment subsamples in the 50 -mL tubes were used as the sources for DNA extractions. The UltraClean ${ }^{\circledR}$ Soil DNA Kit (MO BIO Laboratories, Solana Beach, Calif.) was used for all DNA extractions, following the recommendations of the manufacturer. The physicaldisruption step in the process was accomplished using the FastPrep ${ }^{\circledR}$ FP120 (Qbiogene, Inc., Carlsbad, Calif.) at a setting of 5.5 for 30 seconds (s). Approximately $1.0 \mathrm{~g}$ of total sediment per sample was extracted, and the purified DNA was suspended in a final volume of 50 microliters $(\mu \mathrm{L})$ of sterile water.

The primary polymerase chain-reaction (PCR) amplifications were accomplished using the 787F (5'-ATTAGATACCCTDTAGTCC-3') and 1492R (5'-GGTTACCTTGTTACGACTT3') primer set (Amann and Ludwig, 2000). The KAPA2G Robust HotStart ReadyMix kit (Kapa Biosystems, Boston, Mass.) was used for the DNA polymerase and master-mix components. The master-mix recipe for the primary PCR reactions ( $25 \mu \mathrm{L}$ final volume) consisted of $0.1 \mu \mathrm{L}$ DNA polymerase, $5.0 \mu \mathrm{L}$ Buffer A, 5.0 $\mu \mathrm{L}$ Enhancer, $0.5 \mu \mathrm{L}$ dNTP mixture, $1.0 \mu \mathrm{L}$ of each primer, $5.0 \mu \mathrm{L}$ of DNA substrate, and 7.4 $\mu \mathrm{L}$ sterile water. The thermal cycler (PCR Sprint; Thermo Electron Corp., Waltham, Mass.) program for this primer set was $30 \mathrm{~s}$ at $95^{\circ} \mathrm{C} ; 30 \mathrm{~s}$ at $95^{\circ} \mathrm{C}, 30 \mathrm{~s}$ at $50^{\circ} \mathrm{C}, 30 \mathrm{~s}$ at $72^{\circ} \mathrm{C}(30 \mathrm{cycles}) ; 1$ minute $(\mathrm{min})$ at $72^{\circ} \mathrm{C}$. All primary PCR products were stored at ${ }^{-} 20^{\circ} \mathrm{C}$.

The nested PCR used primer 1070F (5'-ATGGCTGTCGTCAGCT-3') and 1392Rgc (5'CGCCCGCCGCGCCCCGCGCCCGGCCCGCCGCCCCCGCCCCACGGGCGGTGTGTAC-

3') (Ferris and others, 1996; 1997), where the underlined sequence imparts the specificity of the 
primer and the non-underlined sequence represents the non-annealing GC-tail. The PCR master mix for the nested reactions included (50 $\mu \mathrm{L}$ final volume) $0.2 \mu \mathrm{L}$ DNA polymerase, $10.0 \mu \mathrm{L}$ Buffer A, 10.0 $\mu \mathrm{L}$ Enhancer, $1.0 \mu \mathrm{L}$ dNTP mixture, $2.0 \mu \mathrm{L}$ of each primer, $2.0 \mu \mathrm{L}$ of DNA substrate, and $22.8 \mu \mathrm{L}$ sterile water. The thermal cycler (PCR Sprint; Thermo Electron Corp., Waltham, Mass.) program for this primer set was $30 \mathrm{~s}$ at $95^{\circ} \mathrm{C} ; 30 \mathrm{~s}$ at $95^{\circ} \mathrm{C}, 30 \mathrm{~s}$ at $52^{\circ} \mathrm{C}, 30 \mathrm{~s}$ at $72^{\circ} \mathrm{C}(30$ cycles $) ; 1 \mathrm{~min}$ at $72^{\circ} \mathrm{C}$. All nested PCR products were stored at ${ }^{-} 20^{\circ} \mathrm{C}$.

Denaturing-gradient gels (Muyzer and Smalla, 1998) were double-gradient gels with an acrylamide concentration range of 6 to 12 percent and a denaturant range of 35 to 80 percent [where a 100-percent solution is defined as 40 percent (v/v) formamide plus 7.0 molar (M) urea]. All gels and running solutions were made with $1 \mathrm{X}$ TAE (0.04 M Tris base, $0.02 \mathrm{M}$ sodium acetate, $1.0 \mathrm{mM}$ EDTA; $\mathrm{pH} 7.5)$. A subsample $(25 \mu \mathrm{L})$ of each nested PCR product was loaded into separate wells of the gel. A set of GC-clamped PCR products was loaded into three lanes for reference standards. Each gel was run at $60^{\circ} \mathrm{C}$ at approximately 85 volts (V) for 16 hours (hr). All gels were stained with SYBR Gold ( $1 \times$ final concentration) (Invitrogen, Carlsbad, Calif.) for 30 min and then digitally photographed.

A digital image of each gel was loaded into the nucleic-acid banding-and-fingerprint analysis software, GelCompar II (Applied Maths, Austin, Tex.). The banding pattern or fingerprint from each sample was first normalized and then analyzed for similarity, relative to the standard. The resulting similarity dendrogram was generated using the unweighted-pairgroup method with arithmetic averages (UPGMA) and the Dice similarity coefficient.

\section{Results}

The microbial community nucleic-acid extraction, PCR amplification, and DGGE procedures produced a reliable community fingerprint for all samples. The microbial 
community-diversity dendrogram, based on DNA fingerprint banding-pattern similarities, is shown in figure 2. The numeric value at each node in the branching pattern of the dendrogram is the cophenetic correlation-coefficient value. This value expresses the consistency or reliability of the sequence groupings to the right of the respective values, with 100 indicating an identical match between fingerprints.

Data on the presence or absence of petroleum hydrocarbons in sediments from the same locations were taken from the report by Rosenbauer and others (2011). The data were used to identify sample sites in this study that had and had not been shown to have been contaminated at some level by oil from a non-Deepwater Horizon source. Table 1 denotes those samples in which oil and (or) petroleum hydrocarbons of some type were detected (Y), or oil and (or) petroleum hydrocarbons were detected but with a limited biomarker dataset $(*)$, or that showed no oil and (or) petroleum hydrocarbon contamination $(\mathrm{N})$ was present. In figure 1, sites where oil and (or) petroleum hydrocarbons were and were not detected are highlighted in red and white, respectively. Those where oil and (or) petroleum hydrocarbons were detected but with limited biomarkers are highlighted in blue.

Interestingly, 36 (57.1 percent) of the sampled sites were shown to contain a detectable concentration of oil, while another six sites (9.5 percent) contained a limited set of biomarkers for oil. Collectively, 66.7 percent of the samples collected prior to landfall of the Deepwater Horizon oil were positive for the presence of oil. Twenty-one samples (33.3 percent) contained no detectable traces of oil of any type. The samples from LA-26, LA-33, LA-34, FL-10 and FL20 had the most unique community fingerprints, and oil was detected in all of them.

There is a general grouping of sample sites by State based on similar microbial community fingerprints and the presence of non-Deepwater Horizon oil (fig. 2). The eastern- 
most sample sites from Alabama to Florida that did not have detectable oil showed the most similar community-fingerprint patterns. However, there was no absolute clustering of samples based on the presence or absence of oil. All dendrogram groups contained both sample classifications.

These conflicting observations may be due to microbial communities within the sediment systems of the Gulf of Mexico having been exposed to crude oils for millennia, including the present, and are therefore acclimated for degrading oil at these sites. Kvenvolden and Cooper (2003) estimated the Gulf of Mexico receives approximately 140,000 metric tons $\left(\sim 1.0 \times 10^{6}\right.$ barrels) of crude oil per year from natural seeps. Accordingly, microbial communities in the Gulf of Mexico contain a relatively cosmopolitan group of microorganisms capable of degrading crude oil without dramatic changes (that is, succession with increase in biomass) in diversity (Hazen and others, 2010; Orcutt and others, 2010).

Another contributing factor to these conflicting observations is that microbial diversity can be dramatically different between two samples that are collected just meters apart. For example, only the community fingerprints from replicate samples TX-51, LA-23, LA-31, MS-38, and MS-45 were similar enough to be closely grouped. The remaining sites at which replicate samples were collected (FL-6, FL-7, FL-11, FL16, FL-18) had community fingerprints, and therefore diversity, that were significantly different within the respective replicate samples. This lack of uniformity in community-fingerprint profiles within replicate sample sets is influenced by, but not limited to, patchiness in the distribution of (1) types and concentrations of nutrients, (2) electron donors and acceptors, and (3) the presence of burrowing macrofauna. 


\section{Conclusions}

Microbial community DNA was extracted from coastal-sediment samples at locations in the Gulf of Mexico identified as being ecologically sensitive and having a high potential of being contaminated from the Deepwater Horizon oil spill. Specific sequences within the DNA samples were amplified using PCR and separated using DGGE to produce microbial community fingerprints based on the number and location of DNA bands. Non-Deepwater Horizon oil was detected at 66.7 percent of the sites sampled, indicating oil originating from natural seeps, nonDeepwater Horizon spills, and (or) vessel discharges occurring in these areas. The microbial community fingerprints from sediment samples that had been shown to contain some level of oil did generally group together, indicating the oil present in those sediments produced a niche that was predominantly colonized by a community of common microbes. However, there were community fingerprints within these same groupings from sediment samples that had been shown to be free of any oil.

Microbial communities systematically degrade carbon substrates (for example, crude oil) into metabolic by-products and carbon dioxide. This response is controlled by other factors such as, but not limited to, sediment characteristics, temperature, dissolved-oxygen concentrations, nitrogen and phosphorus nutrient concentrations, and phytoplankton blooms. This natural degradation process is performed by a succession of microbial species within the existing community that is characterized by increases in biomass of the active species over time. The succession of microbial species can be monitored by determining microbial community fingerprints like those generated in this study. However, a single sample provides only a snapshot of which species are present at a single time point in the community response or degradation process and provides no insight into the rates of crude-oil degradation by microbial 
communities. The collaborations of geochemists and microbial ecologists could provide data on oil-degradation rates, by-products produced by the microbial activities in the sediments, and environmental factors that modulate these processes.

\section{Acknowledgments}

The USGS funded this pre-impact sampling and analytical study, and additional funding was later provided by the U.S. Coast Guard. We thank Christina Kellogg, Hilary Stockdon, and Mike Gray for thoughtful reviews of an earlier version of the manuscript that improved this report. We thank also Norris Comer for performing the initial processing of the sediment samples, Barbara Lidz and Heather Schreppel for editorial and technical support, and Matt Streubert for generating the map resources.

\section{References Cited}

Amos, John, 2010, BP spill was greater disaster than public knew: SkyTruth news release, http://mcbi.org/news/PR-Norse-Amos-2010.pdf.

Amann, R., and Ludwig, W., 2000, Ribosomal RNA-targeted nucleic acid probes for studies in microbial ecology: Federation of European Microbiological Societies Microbiology Reviews, v. 24, p. 555-565.

Crone, T.J., and Tolstoy, Maya, 2010, Magnitude of the 2010 Gulf of Mexico oil leak: Science, v. 330, p. 634 .

Ferris, M.J., Muyzer, G., and Ward, D.M., 1996, Denaturing gradient gel electrophoresis profiles of $16 \mathrm{~S}$ rRNA-defined populations inhabiting a hot spring microbial mat community: Applied and Environmental Microbiology, v. 62, p. 340-346. 
Ferris, M.J., Nold, S.C., Revsbech, N.P., and Ward, D.M., 1997, Population structure and physiological changes within a hot spring microbial mat community following disturbance: Applied and Environmental Microbiology, v. 63, p. 1367-1374.

Hazen, T.C., Dubinsky, E.A., DeSantis, T.Z., and others, 2010, Deep-sea oil plume enriches indigenous oil-degrading bacteria, 2010: Science, v. 330, no. 6001, p. 204-208.

Kvenvolden, K.A., and Cooper, C.K., 2003, Natural seepage of crude oil into the marine environment. Geo-Marine Letters, v. 23, p. 140-146.

Muyzer, Gerald, and Smalla, Kornelia, 1998, Application of denaturing gradient gel electrophoresis (DGGE) and temperature gradient gel electrophoresis (TGGE) in microbial ecology: Antonie van Leeuwenhoek, v. 73, p. 127-141.

Orcutt, B.N., Joye, S.B., Kleindienst, S., Knittel, K., Ramette, A., Reitz, A., Samarkin, V., Treude, T., and Boetius, A., 2010, Impact of natural oil and higher hydrocarbons on microbial diversity, distribution, and activity in Gulf of Mexico cold-seep sediments: Deep-Sea Research II, v. 57, p. 2008-2021.

Rosenbauer, R.J., Campbell, P.L., Lam, Angela, Lorenson, T.D., Hostettler, F.D., Thomas, Burt, and Wong, F.L., 2011, Petroleum hydrocarbons in sediment from the nothern Gulf of Mexico shoreline, Texas to Florida: U.S. Geological Survey Open-File Report 20111014, 22 p. [http://pubs.usgs.gov/of/2011/1014/.]

U.S. Geological Survey, variously dated, National field manual for the collection of waterquality data: U.S. Geological Survey Techniques of Water-Resources Investigations, book 9, chaps. A1-A9. [http://pubs.water.usgs.gov/twri9A.] 
Wilde, F.D., Skrobialowski, S.C., and Hart, J.S., 2010, Sampling protocol for post-landfall Deepwater Horizon oil release, Gulf of Mexico, 2010: U.S. Geological Survey Open-File Report 2010-1191, 155 p. [http://pubs.usgs.gov/of/2010/1191/.] 


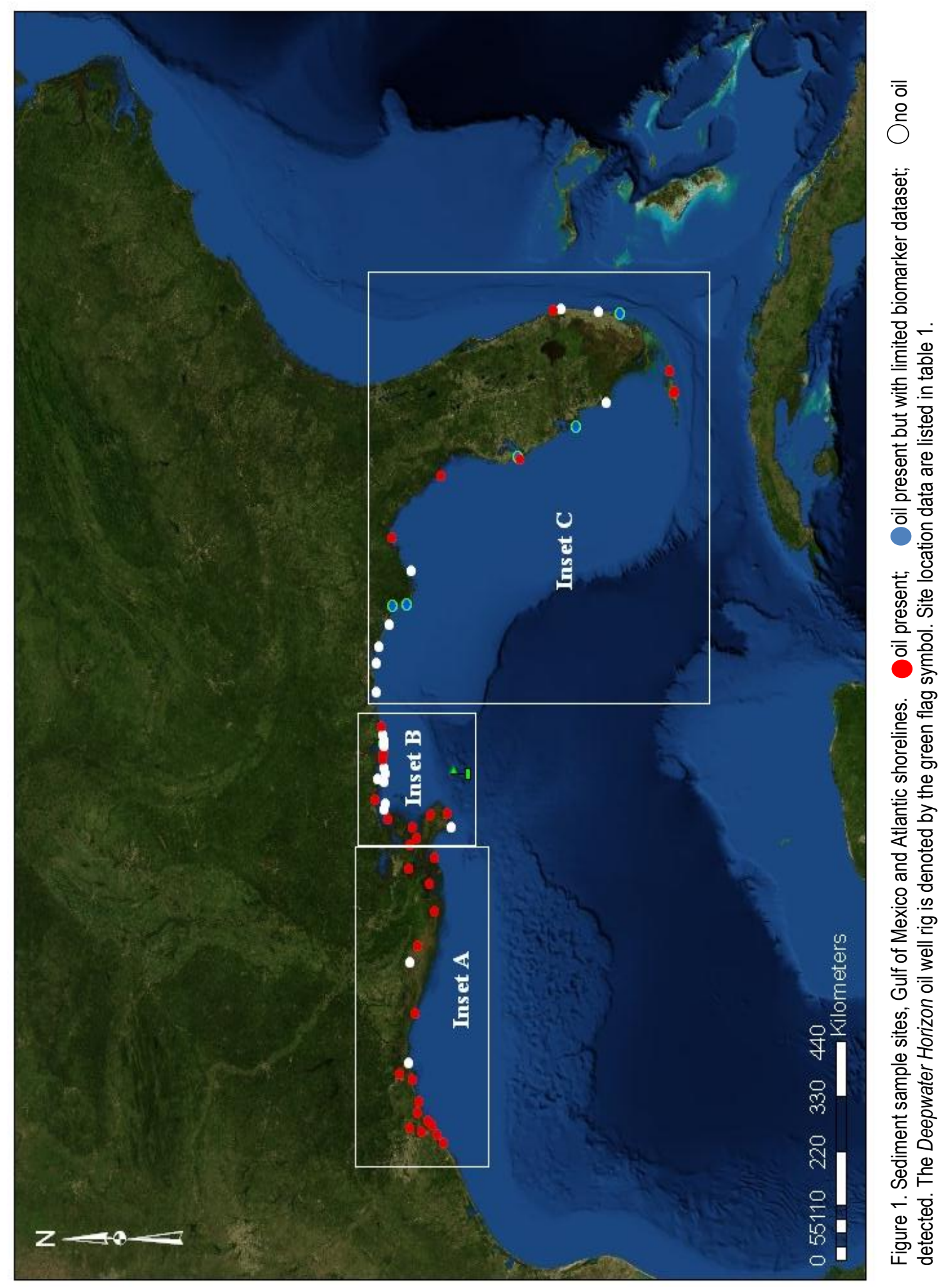




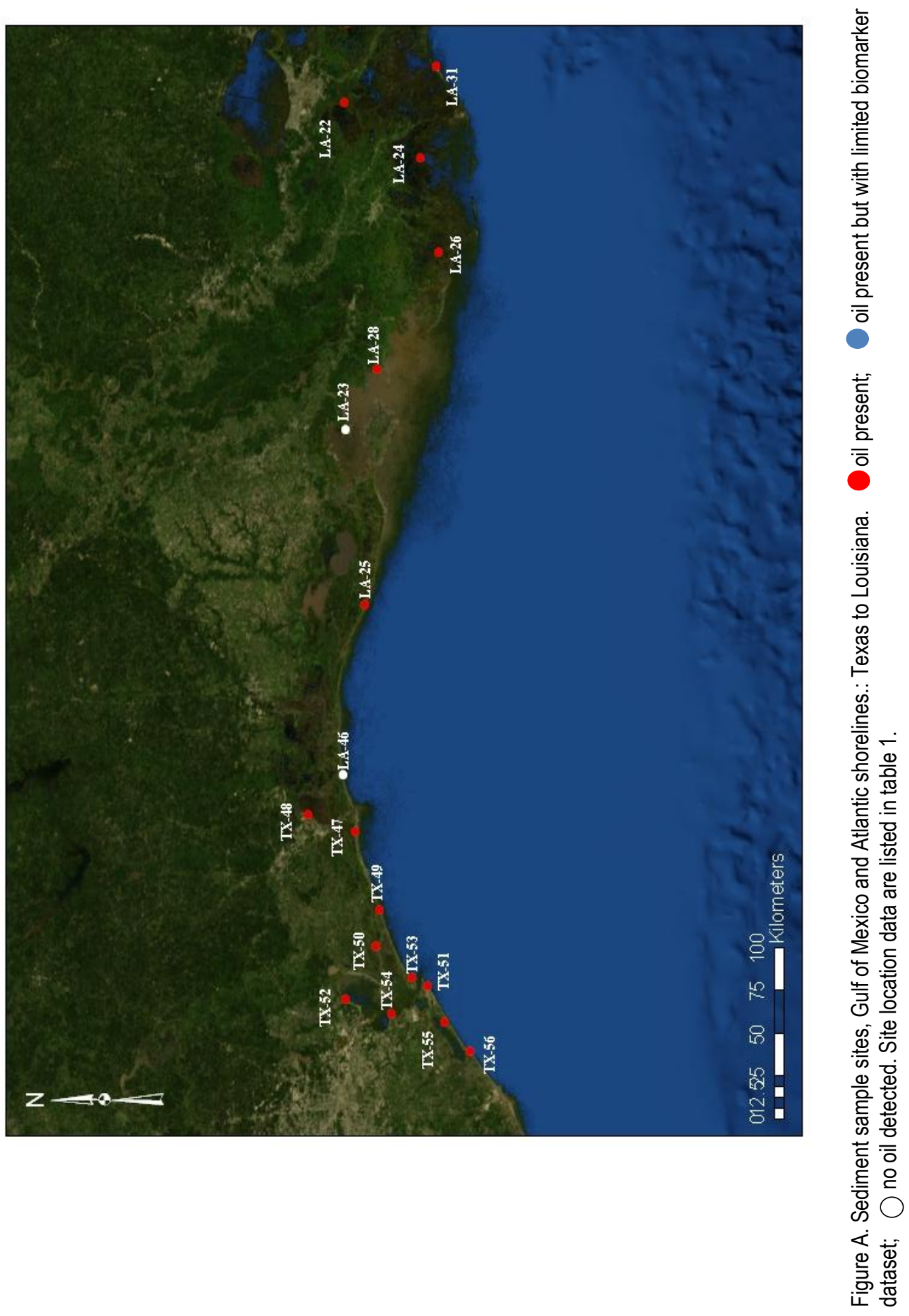




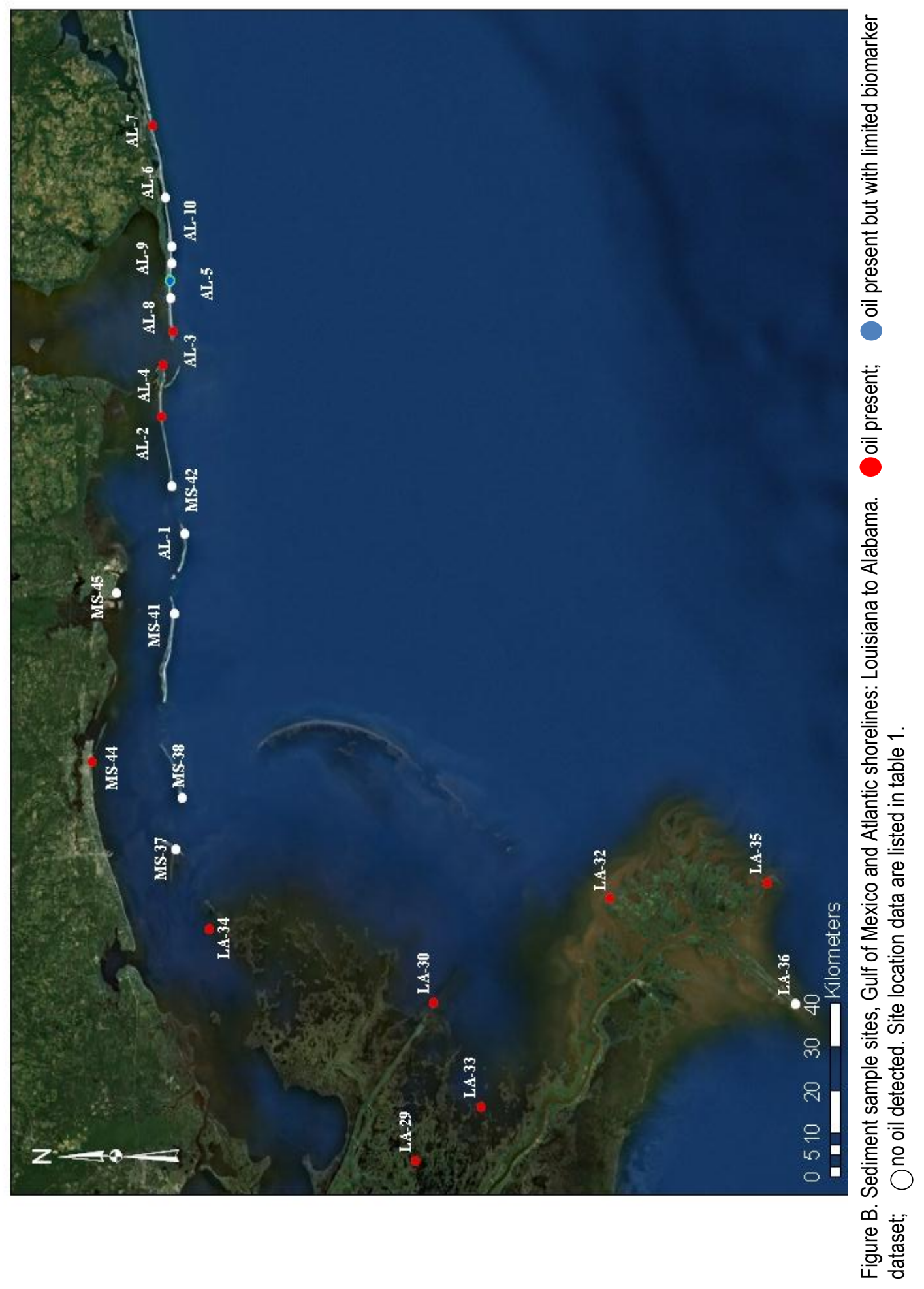




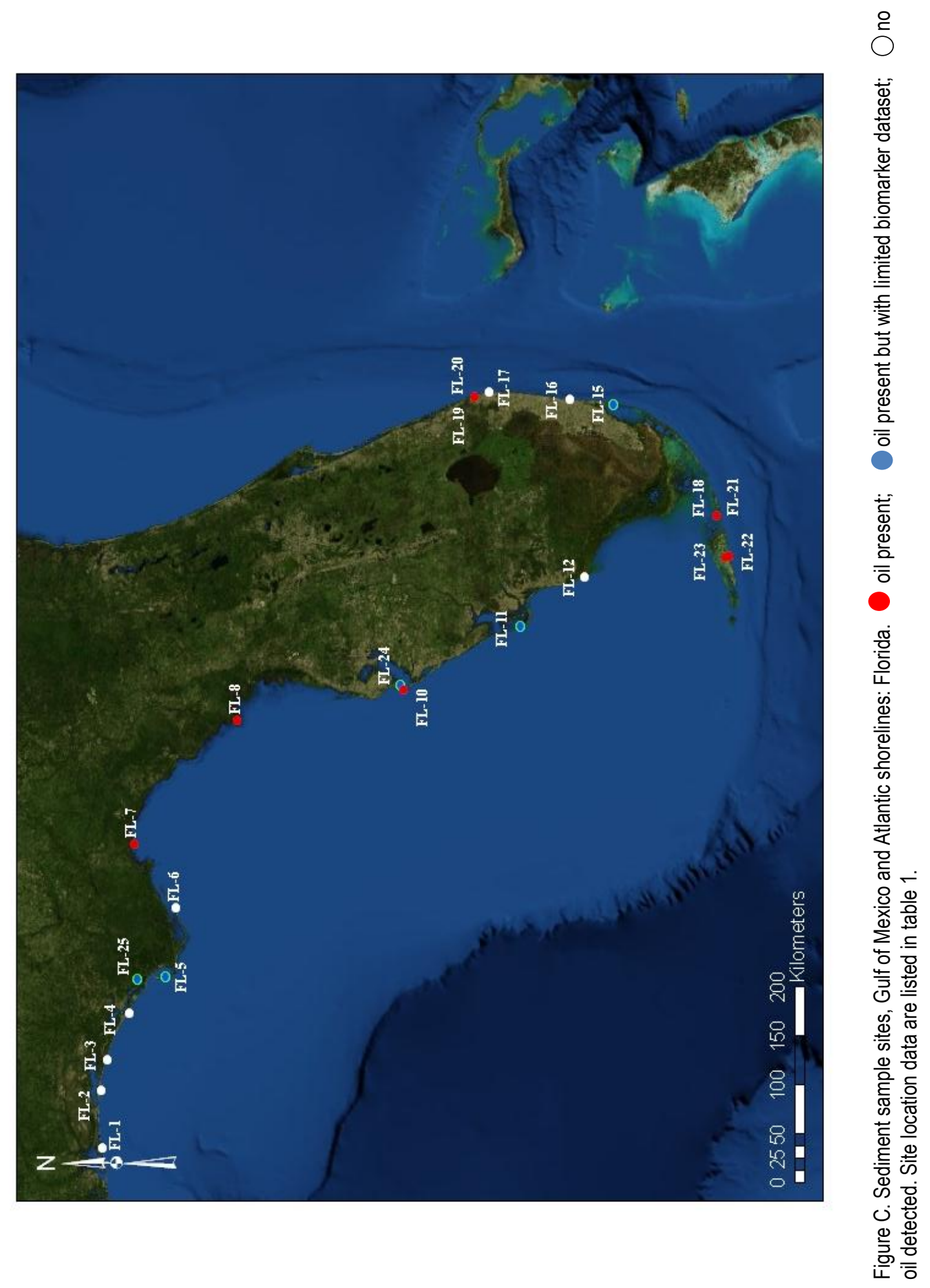


Figure 2. Sediment sample similarity dendrogram. Colors are correlated with those in figure 1.

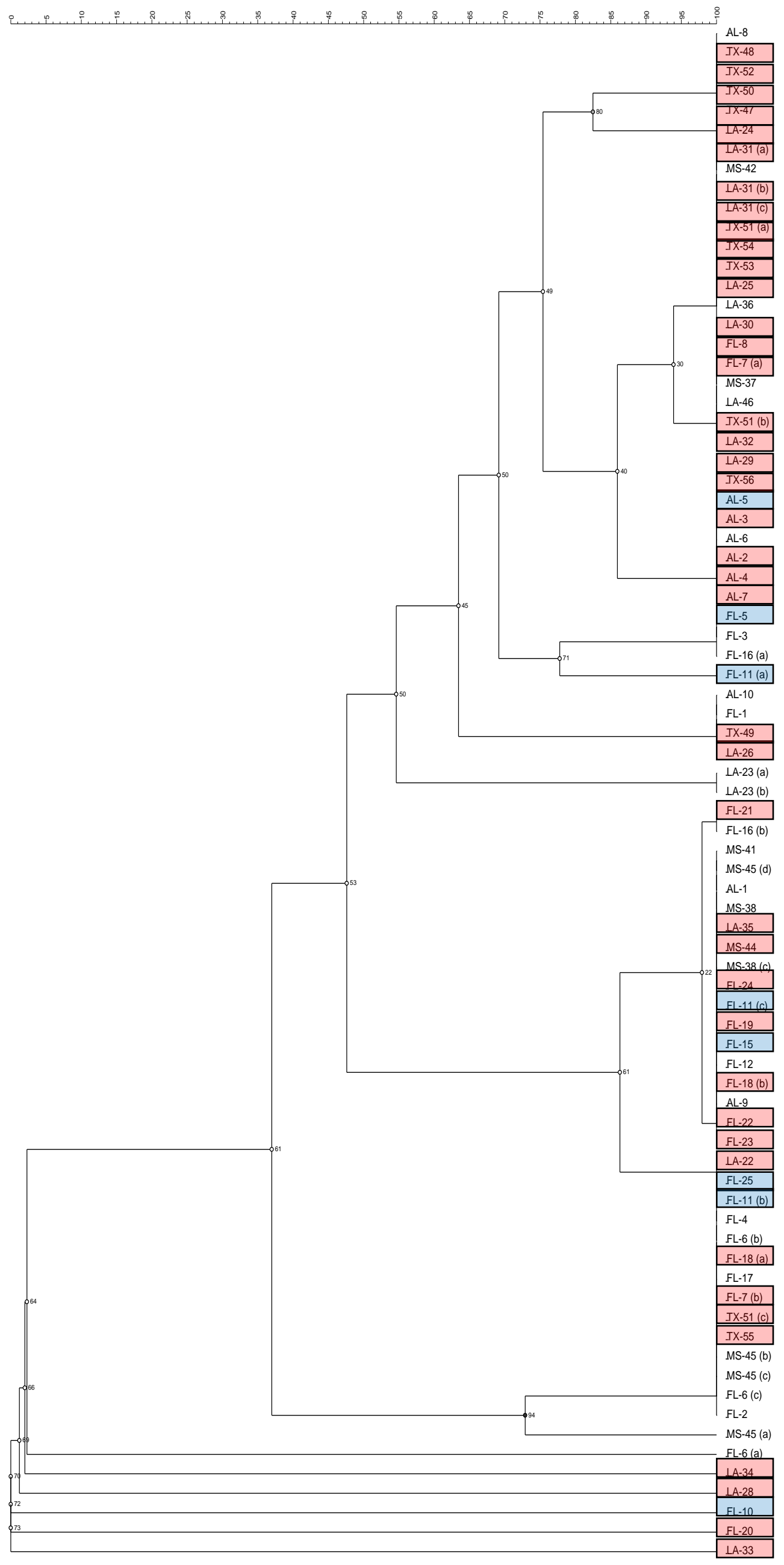


Table 1. Sediment samples, Gulf of Mexico and Atlantic shorelines.

[Y, oil present; " , oil present but with limited biomarker set; $\mathrm{N}$, no oil detected ]

\begin{tabular}{cccc}
$\begin{array}{c}\text { Map } \\
\text { Site } \\
\text { Label }\end{array}$ & Sample Site Name & Latitude & Longitude \\
& (decimal degrees) & Sample Date & $\begin{array}{c}\text { Oil } \\
\text { Present }{ }^{1}\end{array}$ \\
\hline \hline
\end{tabular}

\begin{tabular}{|c|c|c|c|c|c|}
\hline TX-47 & Texas Point & 29.682500 & -93.956389 & $5 / 10 / 10$ & Y \\
\hline TX-48 & Sabine Lake & 29.928333 & -93.871389 & $5 / 10 / 10$ & $\mathrm{Y}$ \\
\hline TX-49 & High Island & 29.556667 & -94.368333 & $5 / 10 / 10$ & Y \\
\hline TX-50 & East Bay near Anahuac & 29.574722 & -94.555833 & $5 / 10 / 10$ & Y \\
\hline TX-51 & Galveston Island & 29.304167 & -94.769444 & $5 / 10 / 10$ & Y \\
\hline TX-52 & Trinity Bay near Beach City & 29.735556 & -94.836389 & $5 / 11 / 10$ & Y \\
\hline TX-53 & Bolivar Peninsula & 29.388333 & -94.719167 & $5 / 11 / 10$ & Y \\
\hline TX-54 & Galveston Bay near Eagle Point & 29.493611 & -94.911111 & $5 / 11 / 10$ & Y \\
\hline TX-55 & West Bay, Galveston Island State Park & 29.214167 & -94.953889 & $5 / 11 / 10$ & Y \\
\hline TX-56 & San Luis Pass & 29.086667 & -95.108611 & $5 / 11 / 10$ & Y \\
\hline LA-22 & Jean Lafitte National Park & 29.742222 & -90.141944 & $5 / 14 / 10$ & Y \\
\hline LA-23 & Cypremort Point & 29.735000 & -91.853611 & $5 / 13 / 10$ & $\mathrm{~N}$ \\
\hline LA-24 & Lake Felicity & 29.346111 & -90.429167 & $5 / 18 / 10$ & $\mathrm{Y}$ \\
\hline LA-25 & Rockefeller Refuge Beach & 29.635556 & -92.767222 & $5 / 13 / 10$ & Y \\
\hline LA-26 & Sister Lake & 29.251944 & -90.921667 & $5 / 17 / 10$ & Y \\
\hline LA-28 & Point Chevreuil & 29.573333 & -91.537778 & $5 / 13 / 10$ & $\mathrm{Y}$ \\
\hline LA-29 & Crooked Bayou & 29.723333 & -89.723611 & $5 / 18 / 10$ & Y \\
\hline LA-30 & Mississippi River Gulf Outlet & 29.685556 & -89.395833 & $5 / 7 / 10$ & Y \\
\hline LA-31 & Grand Isle Beach State Park & 29.260278 & -89.950278 & $5 / 10 / 10$ & $\mathrm{Y}$ \\
\hline LA-32 & Mississippi River at Main Pass & 29.320556 & -89.181944 & $5 / 7 / 10$ & Y \\
\hline LA-33 & Breton Sound & 29.588333 & -89.611944 & $5 / 7 / 10$ & Y \\
\hline LA-34 & Mississippi Sound at Grand Pass & 30.151944 & -89.245833 & $5 / 7 / 10$ & Y \\
\hline LA-35 & Mississippi River at South Pass & 28.997500 & -89.148889 & $5 / 7 / 10$ & Y \\
\hline LA-36 & Mississippi River at Southwest Pass & 28.937500 & -89.398889 & $5 / 7 / 10$ & $\mathrm{~N}$ \\
\hline LA-46 & East Sabine & 29.748889 & -93.663333 & $5 / 10 / 10$ & $\mathrm{~N}$ \\
\hline MS-37 & South Cat Island Beach & 30.219167 & -89.079722 & $5 / 7 / 10$ & $\mathrm{~N}$ \\
\hline MS-38 & West Ship Island Beach & 30.207500 & -88.972222 & $5 / 7 / 10$ & $\mathrm{~N}$ \\
\hline MS-41 & East Horn Island Beach & 30.222500 & -88.592500 & $5 / 8 / 10$ & $\mathrm{~N}$ \\
\hline MS-42 & Petit Bois Island Beach & 30.202222 & -88.426667 & $5 / 8 / 10$ & $\mathrm{~N}$ \\
\hline MS-44 & Biloxi Beach & 30.393333 & -88.899444 & $5 / 8 / 10$ & Y \\
\hline MS-45 & Pascagoula Beach & 30.342778 & -88.547778 & $5 / 8 / 10$ & $\mathrm{~N}$ \\
\hline$A L-1$ & West Dauphin Island & 30.227425 & -88.326300 & $5 / 8 / 10$ & $\mathrm{~N}$ \\
\hline AL-2 & Dauphin Island & 30.248815 & -88.184168 & $5 / 9 / 10$ & Y \\
\hline AL-3 & Dauphin Island & 30.246870 & -88.077777 & $5 / 9 / 10$ & Y \\
\hline AL-4 & Fort Morgan & 30.224926 & -88.008330 & $5 / 8 / 10$ & $\mathrm{Y}$ \\
\hline AL-5 & Fort Morgan & 30.230481 & -87.904438 & $5 / 8 / 10$ & * \\
\hline AL-6 & Gulf Shores & 30.241314 & -87.730265 & $5 / 8 / 10$ & $\mathrm{~N}$ \\
\hline AL-7 & Orange Beach & 30.269091 & -87.581649 & $5 / 8 / 10$ & $\mathrm{Y}$ \\
\hline AL-8 & BLM Tract 1 at Fort Morgan & 30.231593 & -87.937772 & $5 / 24 / 10$ & $\mathrm{~N}$ \\
\hline AL-9 & BLM Tract 2 at Fort Morgan & 30.228815 & -87.867214 & $5 / 24 / 10$ & $\mathrm{~N}$ \\
\hline$A L-10$ & BLM Tract 3 at Fort Morgan & 30.228259 & -87.831102 & $5 / 24 / 10$ & $\mathrm{~N}$ \\
\hline
\end{tabular}


Table 1 (cont.). Sediment samples, Gulf of Mexico and Atlantic shorelines.

[Y, oil present; " , oil present but with limited biomarker set; N, no oil detected ]

\begin{tabular}{|c|c|c|c|c|c|}
\hline $\begin{array}{c}\text { Site } \\
\text { Label }\end{array}$ & Sample Site Name & $\begin{array}{l}\text { Latitude } \\
\text { (decim }\end{array}$ & $\begin{array}{l}\text { Longitude } \\
\text { grees) }\end{array}$ & Sample Date & Oil \\
\hline FL-1 & Gulf Island National Shores Park near Navarre & 30.362389 & -86.970167 & $5 / 11 / 10$ & $\mathrm{~N}$ \\
\hline FL-2 & Henderson Beach State Park near Destin & 30.382944 & -86.442778 & $5 / 11 / 10$ & $\mathrm{~N}$ \\
\hline FL-3 & Grayton Beach State Park near Seaside & 30.324056 & -86.155056 & $5 / 12 / 10$ & $\mathrm{~N}$ \\
\hline FL-4 & St. Andrews State Park near Panama City & 30.124722 & -85.736028 & $5 / 12 / 10$ & $\mathrm{~N}$ \\
\hline FL-5 & St. Joe Beach State Park near Port St. Joe & 29.779167 & -85.408528 & $5 / 13 / 10$ & * \\
\hline FL-6 & St. George Island State Park near East Point & 29.697861 & -84.767750 & $5 / 13 / 10$ & $\mathrm{~N}$ \\
\hline FL-7 & St. Marks National Wildlife Refuge near St. Marks & 30.074194 & -84.180444 & $5 / 18 / 10$ & Y \\
\hline FL-8 & Rockefeller Refuge Beach & 29.127750 & -83.053361 & $5 / 18 / 10$ & Y \\
\hline FL-10 & Fort DeSoto Park near St. Petersburg & 27.624444 & -82.738333 & $5 / 17 / 10$ & * \\
\hline FL-11 & Captiva Island Beach near Captiva Island & 26.525639 & -82.194222 & $5 / 20 / 10$ & * \\
\hline FL-12 & Tiger Tail Beach at Marco Island & 25.936139 & -81.734583 & $5 / 21 / 10$ & $\mathrm{~N}$ \\
\hline FL-15 & Bill Baggs Cape near Key Biscayne & 25.667417 & -80.155528 & $6 / 1 / 10$ & * \\
\hline FL-16 & Lloyd Beach at Ft. Lauderdale & 26.081694 & -80.109444 & $5 / 26 / 10$ & $\mathrm{~N}$ \\
\hline FL-17 & MacArthur Beach at West Palm Beach & 26.822583 & -80.038056 & $5 / 27 / 10$ & $\mathrm{~N}$ \\
\hline FL-18 & Coco Plum Beach near Marathon & 24.729250 & -81.169972 & $5 / 24 / 10$ & Y \\
\hline FL-19 & BLM Tract 1 near Jupiter Inlet & 26.956111 & -80.081667 & $6 / 16 / 10$ & Y \\
\hline FL-20 & BLM Tract 2 near Jupiter Inlet & 26.956111 & -80.081944 & $6 / 16 / 10$ & Y \\
\hline FL-21 & BLM Tract 1 near Park Key & 24.650556 & -81.557500 & $6 / 9 / 10$ & Y \\
\hline FL-22 & BLM Tract 2 near Sugarloaf Key & 24.617500 & -81.543611 & $6 / 9 / 10$ & Y \\
\hline FL-23 & BLM Tract 3 near Sugarloaf Key & 24.616667 & -81.539722 & $6 / 9 / 10$ & Y \\
\hline FL-24 & BLM Tract 4 at Egmont Key & 27.601389 & -82.763611 & $6 / 14 / 10$ & Y \\
\hline FL-25 & BLM Lathrop Bayou near Panama City & 30.038944 & -85.435472 & $6 / 10 / 10$ & * \\
\hline
\end{tabular}

${ }^{1}$ Rosenbauer and others (2011) 